\title{
Pengaruh Ekstrak Daun Sukun (Artocarpus altilis) Terhadap Kepadatan Kolagen dalam Proses Penyembuhan Luka Eksisi Tikus Putih (Rattus norvegicus)
}

\section{The Effect of Sukun Leaf (Artocarpus altilis) Extract on Collagen Density of Excision Wound Healing in Albino Rats (Rattus norvegicus)}

\author{
Rizka Wulan Cahya ${ }^{1 *}$, Ira Sari Yudaniayanti², Prima Ayu Wibawati ${ }^{3}$, Maya \\ Nurwartanti Yunita ${ }^{4}$, Nusdianto Triakoso², Amung Logam Saputro ${ }^{2}$ \\ ${ }^{1}$ Pendidikan Profesi Dokter Hewan, ${ }^{2}$ Departemen Klinik Veteriner, ${ }^{3}$ Departemen Kesehatan Masyarakat \\ Veteriner, ${ }^{4}$ Departemen Patologi Veteriner, \\ Fakultas Kedokteran Hewan, Universitas Airlangga, \\ Kampus C Mulyorejo, Surabaya, Jawa Timur, Indonesia, 60115 \\ *Corresponding author: rizka.wulan.cahya-2015@fkh.unair.ac.id
}

\begin{abstract}
Abstrak
Tujuan dari penelitian ini adalah untuk mengetahui pengaruh ekstrak daun sukun (Artocarpus altilis) terhadap kepadatan serabut kolagen dalam penyembuhan luka eksisi pada tikus putih (Rattus norvegicus). Dua puluh ekor tikus jantan dibagi secara acak menjadi lima kelompok, terdapat kontrol negatif (K-) yang diberikan basis salep, kontrol positif $(\mathrm{K}+)$ yang diberikan povidone iodine $10 \%$, kelompok perlakuan (P1, P2, P3) yang diberikan salep ekstrak daun sukun 6,25\%; 12,5\%; dan 25\%. Terapi diberikan sekali sehari selama empat belas hari. Hasil uji nonparametrik Kruskal-Wallis menunjukkan perbedaan nyata $(\mathrm{p}<0,05)$ dan dilanjutkan dengan uji Mann-Whitney. kelompok kepadatan kolagen P1, P2, dan P3 tidak berbeda nyata ( $>0,05)$, tet api berbeda nyata dengan kelompok $\mathrm{K}$ - dan $\mathrm{K}+$. Kesimpulan dari penelitian ini adalah ekstrak daun sukun efektif untuk meningkatkan kepadatan kolagen dalam proses penyembuhan luka eksisi.
\end{abstract}

Kata kunci: daun sukun, eksisi, penyembuhan luka, kolagen

Abstract

The aim of this study was to determine the effect of sukun leaf (Artocarpus altilis) extract on collagen density of excision wound healing in albino rats (Rattus norvegicus). A total of 20 male albino rats were randomly devided into five groups, there were negative control (K-) treated with ointment base, positive control $(\mathrm{K}+)$ treated with povidone iodine $10 \%$, treated groups $(\mathrm{P} 1, \mathrm{P} 2, \mathrm{P} 3)$ treated with sukun leaf extract ointment $6,25 \% ; 12,5 \%$; and $25 \%$. Treatment was given every other day for fourteen days. Results of the nonparametric test Kruskal-Wallis showed significant difference $(\mathrm{p}<0,05)$ and continued with the Mann-Whitney test. Collagen density groups of P1, P2, and P3 did not different significantly ( $>00,05)$, but significantly different from group $\mathrm{K}$ - and $\mathrm{K}+$. The conclusion of this study was sukun leaf extract effective to increase the density of collagen in the healing process of excision wound.

Key words: sukun leaf, excision, wound healing, collagen

Received: 9 Mei 2019

Revised: 18 Juni 2019

Accepted: 11 Juli 2019

\section{PENDAHULUAN}

Kulit merupakan organ terbesar yang menutupi seluruh tubuh dan berfungsi sebagai proteksi dari berbagai macam gangguan baik berupa pengaruh fisik maupun kimia, sehingga kulit sangat rentan terhadap trauma dan terjadinya luka (Kawulusan, dkk, 2015).
Luka dapat terjadi akibat kerusakan atau komponen jaringan yang secara spesifik terdapat substansi jaringan yang rusak atau hilang (Carey, 1997). Salah satu jenis luka adalah luka eksisi yang diakibatkan terpotongnya jaringan oleh goresan benda tajam (Singer dan Dagum, 2008). Adanya jaringan yang rusak atau hilang tersebut maka tubuh akan merespon dan memicu proses 
penyembuhan luka (Pradipta, 2010). Penyembuhan melalui beberapa fase penyembuhan luka yaitu fase hemostasis, fase inflamasi, fase proliferasi dan fase remodeling (McGavin dan James, 2016). Tanda kesembuhan luka yaitu dengan adanya pembentukan kolagen (Paramita, 2016).

Perawatan luka yang biasa dilakukan dengan menggunakan bahan antiseptikseperti povidone iodine $10 \%$. Kandungan povidone iodine $10 \%$ yang dimiliki Betadine ${ }^{\circledR}$ masih menjadi alternatif untuk perawatan luka dikarenakan penggunaannya mudah, mudah didapatkan dan harganya murah namun bahan antiseptik yang terkandung dalam povidone iodine dapat dianggap benda asing oleh tubuh karena komponen dan susunannya berbeda dengan sel tubuh (Nurdiantini, dkk., 2017). Penggunaan povidone iodine juga dapat menghambat pertumbuhan fibroblas sehingga dapat menurunkan sintesis kolagen (Putri, dkk,. 2015).

Usaha untuk menemukan suatu agen penyembuhan luka yang efektif masih terus dilakukan, salah satunya dengan memanfaatkan spesies tumbuhan yang berpotensi sebagai tumbuhan obat. Tumbuhan obat pada umumnya memiliki aktivitas biologis dan medis yang luas, tingkat keamanan yang lebih baik, mudah didapatkan, dan biaya yang dikeluarkan untuk mendapatkan obat ini terbilang murah (Pradhan, dkk., 2013). Salah satu tumbuhan obat yang dapat digunakan adalah daun sukun. Daun Sukun (Artocarpus altilis) merupakan salah satu tumbuhan obat yang dapat mempercepat proses penyembuhan luka karena mengandung berbagai senyawa seperti flavonoid, saponin, polifenol, dan tanin (Kurniawan dan Kamalia, 2017).

\section{METODE PENELITIAN}

Sampel yang digunakan pada penelitian ini adalah salep ekstrak daun sukun (SEDS). Serbuk daun sukun dimasukkan ke dalam bejana maserasi dan ditambahkan dengan pelarut metanol sampai serbuk terendam selama 24 jam. Hasil maserasi dilakukan sokletasi kemudian diuapkan dengan rotary evaporator hingga mendapatkan ekstrak daun sukun kental. Hasil kental ekstrak daun sukun kemudian dicampurkan dengan basis salep untuk pembuatan sediaan salep ekstrak daun sukun.

Rancangan penelitian ini menggunakan Rancangan Acak Lengkap. Penilitian ini merupakan penelitian eksperimental laboratorik dengan menggunakan sampel tikus putih Rattus norvegicus dengan populasi karakter yang homogen. Objek yang diamati yaitu kulit hewan coba. Tikus yang digunakan sebanyak 20 ekor dan dibagi menjadi lima kelompok perlakuan yaitu perlakuan K- (kontrol negatif) merupakan tikus dengan luka eksisi dan terapi basis salep, perlakuan $\mathrm{K}+$ (Povidone iodine 10\%) merupakan tikus dengan luka eksisi dan terapi Povidone iodine 10\%(Betadine ${ }^{\circledR}$ ), P1 (SEDS 6,25\%) merupakan tikus dengan luka eksisi dan terapi SEDS 6,25\%, P2 (SEDS 12,5\%) merupakan tikus dengan luka eksisi dan terapi SEDS 12,5\%, P3 (SEDS 25\%) merupakan tikus dengan luka eksisi dan terapi SEDS $25 \%$. Kriteria hewan coba yang digunakan adalah tikus putih jantan dengan umur berkisar antara 10-14 minggu dan memiliki berat badan 140-150 g, serta tidak ada abnormalitas anatomis.

Tikus putih dianastesi dengan xylazin dan ketamin dengan cara intramuskuler (Sardjana dan Diah, 2015). Kemudian punggung tikus putih dicukur dan dilakukan eksisi menggunakan skalpel dengan memotong kulit dengan panjang dan lebar 1 x $1 \mathrm{~cm}$ serta kedalaman hingga seluruh kulit. Tikus putih yang telah dieksisi kemudian diberikan salep satu kali sehari selama 14 hari. Perlakuan pada hari ke 15 tikus putih dieuthanasi dengan cara dekapitasi yang sebelumnya dilakukan anastesi lalu diambil jaringan kulitnya untuk pembuatan preparat histopatologi (Ardana, 2015).

Kepadatan kolagen diinterpretasikan secara semikuantitatif dengan beberapa kriteria. Parameter skoring histopatologi untuk kepadatan kolagen berdasarkan perhitungan lima lapangan pandang, pada obyek pembesaran 400 kali dengan pewarnaan HE (Nussbaum, dkk, 2009), yakni: (skor 0) tidak terdapat adanya serabut kolagen; (skor 1) terdapat fibroblas, pembuluh darah kapiler baru dan serabut kolagen dalam jumlah sedikit (immature); (skor 2) terdapat 
serabut kolagen dalam jumlah sedang (mature dan immature); (skor 3) terdapat serabut kolagen yang dominan.

Data akan diuji dengan Kruskal-Wallis dilanjutkan dengan uji Mann-Whitney $U$ jika terdapat perbedaan yang signifikan $(\mathrm{p}<0.05)$.

\section{HASIL DAN PEMB AHASAN}

Hasil uji statistik Kruskal-Wallis, pada skor kepadatan kolagen luka eksisi tikus putih yaitu 0.008 yang menunjukkan terdapat perbedaan yang nyata $(\mathrm{p}<0.05)$ pada seluruh kelompok perlakuan. Perbedaan diantara kelompok dilanjutkan dengan uji Mann-Whitney $U$ yang menunjukkan hasil $\mathrm{K}$ - dan $\mathrm{K}+$ tidak berbeda nyata $(p>0.05)$, akan tetapi berbeda nyata dengan $\mathrm{P} 1, \mathrm{P} 2$, dan P3 ( $\mathrm{p}<0.05)$. Pelakuan P1 dan P2 tidak berbeda nyata $(p>0.05)$, akan tetapi berbeda nyata dengan P3 ( $<<0.05)$, sedangkan P2 dan P3 tidak berbeda nyata ( $>0.05$ ) (Tabel 1).

Gambar 1 merupakan gambaran histopatologi dari masing-masing kelompok perlakuan. $\mathrm{K}$ - dan $\mathrm{K}+$ menunjukkan bahwa kepadatan kolagen pada kelompok $\mathrm{K}+$ memiliki skor yang lebih tinggi daripada kelompok K-. Gambaran histopatologi kelompok perlakuan P1, P2, dan P3 menunjukkan bahwa skor kepadatan kolagen dari yang tertinggi hingga terendah yaitu P1, P2, dan P3.

Kepadatan kolagen kelompok $\mathrm{K}$ - (basis salep) pada penelitian ini menunjukkan hasil yang paling rendah dibandingkan dengan kelompok $\mathrm{K}+$ (povidone iodine 10\%), P1, P2 dan P3. Pemberian basis salep tanpa ekstrak daun sukun pada penelitian ini digunakan untuk memastikan bahwa bahan ekstrak daun sukun yang memberikan efek penyembuhan luka. Basis salep digunakan sebagai bahan penutup luka untuk menghindari infeksi dan menjaga kelembapan kulit. Basis salep yang digunakan mengandung vaseline flavum yang bersifat sebagai emolient dan moisturizer yang dapat mempertahankan kelembapan kulit (Handayani, dkk., 2016). Adeps lanae dalam basis salep dapat berfungsi sebagai lapisan penutup dan melunakkan kulit (Anief, 1997).
Kepadatan kolagen kelompok $\mathrm{K}+$ (povidone iodine) pada penelitian ini lebih tinggi daripada $\mathrm{K}$ - akan tetapi tidak berbeda nyata dengan P1, P2 dan P3. Hasil tersebut kemungkinan disebabkan karena povidone iodine memiliki sifat sebagai antiseptik, sehingga luka tetap terjaga dari adanya infeksi mikroba. Penelitian sebelumnya menyatakan bahwa secara in vitro pada sel kultur dengan menggunakan povidone iodine dapat menyebabkan efek toksik pada fibroblas yang mengakibatkan pertumbuhan fibroblas terhambat sehingga menghambat stimulasi pembentukan kolagen (Danarti, dkk., 2014).

Kepadatan kolagen kelompok P1 lebih tinggi dibandingkan dengan kelompok kontrol negatif (K-), kontrol positif $(\mathrm{K}+)$, P2 dan P3. Hasil tersebut terjadi karena adanya senyawa aktif dari ekstrak daun sukun yang dapat mempercepat proses penyembuhan luka, selain itu dosis salep ekstrak daun sukun yang tepat juga menyebabkan hasil skor kepadatan kolagen yang tinggi. Hal ini sesuai dengan pernyataan pada penelitian sebelumnya bahwa ekstrak daun sukun memiliki bahan aktif yaitu flavonoid, pholifenol, saponin dan tanin.

Oksigenasi merupakan salah satu faktor yang berpengaruh dalam sintesis kolagen dari fibroblas. Oksigen merupakan ko-faktor yang penting dalam hidroksilasi prolin dan lisin dalam proses pembentukan prokolagen (Hamid dkk., 2019). Selama fase inflamasi, ketika banyak oksigen yang digunakan maka Reactive Oxygen Species (ROS) pun akan banyak diproduksi. ROS merupakan radikal bebas yang di produksi oleh netrofil dan makrofag. ROS dapat mencegah adanya infeksi bakteri akan tetapi ROS yang meningkat pada kondisi patologis dapat memberikan efek berupa kerusakan jaringan sehingga dapat menghambat proses penyembuhan luka (Kurahashi dan Fujii, 2015).

Senyawa yang terkandung dalam ekstrak daun sukun seperti flavonoid dapat mendetoksifikasi ROS karena flavonoid merupakan antioksidan yang dapat menetralisir radikal bebas dengan cara mendonasi satu elektron yang menjadi radikal bebas yang relatif stabil (Arief dan Widodo, 2018). Polifenol juga mempunyai aktivitas sebagai antioksidan sebagai 
Tabel 1. Rata-rata kepadatan kolagen kulit tikus puth pada setiap perlakuan

\begin{tabular}{cc}
\hline Perlakuan & Skoring ke padatan kolagen $(\mathbf{x} \pm$ SD $)$ \\
\hline K- & $0.25^{\mathrm{a}} \pm 0.500$ \\
K + & $0.75^{\mathrm{a}} \pm 0.500$ \\
P1 & $2.50^{\mathrm{c}} \pm 0.577$ \\
P2 & $1.50^{\mathrm{b}} \pm 0.577$ \\
P3 & $1.25^{\mathrm{b}} \pm 0.500$
\end{tabular}

Superskrip berbeda pada kolom yang sama menunjukkan perbedaan signifikan $(\mathrm{p}<0.05)$

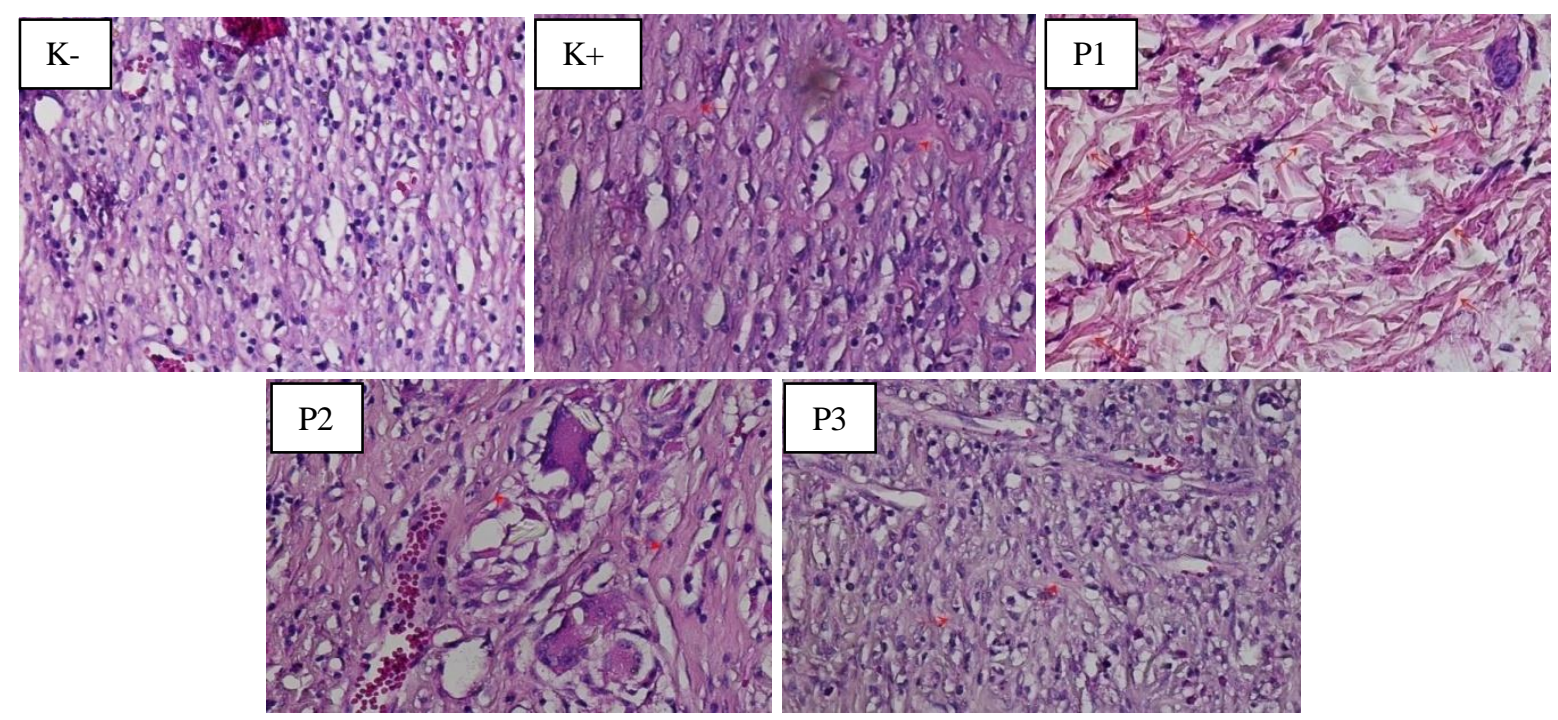

Gambar 1. Serabut kolagen pada mikroskop trinokuler Nikon Eclipse E200 perbesaran 400x

maka akan semakin kecil absorbsi zat aktif.

penangkap dan pengikat radikal bebas (Rohmawati, 2008; Purnama dan Samik, 2014).

Kolagen disintesa terutama oleh fibroblas dengan menghasilkan bahan dasar serat kolagen yang akan mempertautkan tepi luka. Migrasi fibroblas pada area perlukaan distimulasi oleh transforming growth factor $\beta$ (TGF- $\beta$ ) (Hamid dkk., 2018). Saponin dalam ekstrak daun sukun dapat mengaktifkan jalur sinyal TGF- $\beta$. Semakin banyak TGF- $\beta$ yang teraktivasi maka jumlah fibroblas yang bermigrasi ke area luka akan semakin banyak sehingga kolagen yang dihasilkan juga akan semakin banyak (Kanzaki, dkk., 1998; Sucita dkk., 2019).

Kepadatan kolagen kelompok $\mathrm{P} 2$ lebih tinggi daripada $\mathrm{K}-, \mathrm{K}+$ dan $\mathrm{P} 3$, namun lebih rendah dibandingkan dengan kelompok P1. Zat aktif yang terkandung dalam ekstrak daun sukun dapat meningkatkan kepadatan kolagen namun kemampuan masuknya zat aktif ke dalam jaringan kulit dipengaruhi oleh daya sebar. Konsentrasi yang semakin tinggi menyebabkan semakin sulit salep untuk menyebar pada kulit
Daya sebar yang semakin rendah menyebabkan koefisien difusi semakin kecil dengan difusi obat menurun (Andrie dan Dies, 2017).

Kepadatan kolagen kelompok P3 lebih tinggi daripada $\mathrm{K}$ - dan $\mathrm{K}+$, namun lebih rendah dibandingkan dengan kelompok P1 dan P2. Hasil ini disebabkan jumlah basis salep yang digunakan pada salep ektrak daun sukun $25 \%$ kemungkinan belum cukup untuk membuat luka tetap lembap karena konsentrasinya lebih pekat. Jumlah basis salep yang sedikit memungkinkan kemampuan dalam menciptakan lingkungan luka yang lembab juga berkurang (Rahma, 2014). Kadar kelembaban yang rendah dapat mengakibatkan tekanan oksigen dalam jaringan luka menurun sehingga dapat menghambat proses pembentukan kolagen (Novriansyah, 2008).

\section{KESIMPULAN}

Pemberian salep ekstrak daun sukun (Artocarpus altilis) dapat meningkatkan 
kepadatan serabut kolagen dalam proses penyembuhan luka eksisi pada tikus putih (Rattus norvegicus). Salep ekstrak daun sukun $6,25 \%$ merupakan konsentrasi efektif dalam meningkatkan kepadatan serabut kolagen tikus putih (Rattus norvegicus) yang mengalami luka eksisi dibandingkan dengan perlakuan lainnya.

\section{UCAPAN TERIMA KASIH}

Penulis mengucapkan terima kasih kepada Universitas Airlangga PSDKU Banyuwangi atas dukungan fasilitas sehingga penelitian ini dapat diselesaikan. Peneliti juga mengucapkan terima kasih kepada semua pihak yang telah membantu dalam kegiatan penelitian sehingga seluruh kegiatan dapat dilaksanakan dengan baik.

\section{DAFTAR PUSTAKA}

Andrie, M., Dies, S. 2017. Efektivitas Sediaan Salep yang Mengandung Ekstrak Ikan Gabus (Channa striata) pada Proses Penyembuhan Luka Akut Stadium II Terbuka pada Tikus Jantan Galur Wistar. Pontiana. Fakultas Kedokteran Universitas Tanjungpura.

Anief, M. 1997. Formulasi Obat Topikal Dengan Dasar Penyakit Kulit. Universitas Gadjah Mada. Press : Yogyakarta.

Arief, H., Widodo, M.A. 2018. Peranan Stres Oksidatif Pada Proses Penyembuhan Luka. Fakultas Kedokteran. Universitas Wijaya Kusuma Surabaya. J Ilmiah Ked. Wijaya Kusuma, 5(2), 22-29.

Carey, L.C. 1997. Textbook Of Surgery: The Biological Basis Of Modern Surgical Practice. J. Am. Med. Assoc., 278(12), 1038.

Danarti, R., Suswardana., Arief, B., Widodo, W. 2014. The Effect Povidone-Iodine On The Wound Healing Process: A Study On Fibroblast Populated Collagen Lattice (FPCL) Model. Faculty Of Medicine. University Gadjah Mada. Yogyakarta. J. Med. Sci., 46(3), 103-107.
Gurtner, G.C. 2007. Wound Healing : Normal And Abnormal, Grabb And Smith's Plastic Surgery. Sixth Edition. Philadelphia. Hal 1522.

Hamid, I.S., Aksono, E.B., Sukmanadi, M., Purnama, M.T.E. 2018. Antiangiogenesis activity test of tin leaf (Ficus carica L.) on the number of blood vessels and VEGF expression of chorioallantoic membrane of embryonated chicken eggs. Eur. J. Oncol. Pharm., 1(4), e00007.

Hamid, I.S., Ekowati, J., Purnama, M.T.E. 2019. Kaempferia galanga L. Inhibiting Effect on Vascular Endothelial Growth Factor (VEGF) and Cyclooxygenase-2 (Cox-2) Expression on Endothelium of Chorioallantoic Membrane. Indian Vet. J., 96(09), 80-82.

Handayani, F., Reksi S., Henriko N.K. 2016. Aktivitas Etanol Biji Pinang (Areca catecu L.) terhadap Penyembuhan Luka Bakar pada Kulit Punggung Mencit Jantan (Mus musculus). J. Ilmiah Manuntung, 2(2), 158.

Kanzaki, T., Monsaki, N., Shina, R., Saito, Y. 1998. Role Of Transforming Growth FactorB Pathway In The Mechanism Of Wound Healing By Saponin From Gingseng Radix Rubra. Br. J. Pharmacol., 125, 255-62.

Kawulusan, F.R., Sonny, J.R.K., Martha, M.K. 2015. Gambaran Reaksi Radang Luka Antemortem Yang Diperiksa 1 Jam Postmortem Pada Hewan Coba. Fakultas Kedokteran. Universitas Sam Ratulangi. Manado. J. E-Biomed., 2(1), 393-397.

Kurahashi, T., Fujii, J. 2015. Roles of Antioxidative Enzymes in Wound Healing. J. Develop. Biol.

Kurniawan, Y., Kamalia, L. 2017. Pemberian Gel Ekstrak Daun Sukun (Artocarpus altilis) Dapat Mempercepat Proses Penyembuhan Luka Bakar Pada Mencit. Fakultas 
Kedokteran. Universitas Muhammadiyah Palembang. J. Syifa' Med., 8(1), 30-36.

Novriansyah, R. 2008. Perbedaan Kepadatan Kolagen disekitar Luka Insisi Tikus Wistar yang Dibalut Kasa Konvensional dan Penutup Oklusif Hidrokoloid Selama 2 dan 14 Hari [Tesis]. Program Pasca Sarjana Magister Ilmu Biomedik Dan PPDS I Ilmu Bedah Universitas Diponegoro. Semarang.

Nurdiantini, I., Swito, P., Tri, N. 2017. Perbedaan Efek Penggunaan Povidone Iodine 10\% Dengan Minyak Zaitun Terhadap Penyembuhan Luka Robek (Lacerated wound). Fakultas Ilmu Kesehatan. Universitas Tribhuwana Tunggadewi. Malang. Nursing News, 2(1), 511-523.

Nussbaum, E.L., Kenneth, P., Tony, M., Facundo, L.H., Fang, J., Lothar, L. 2009. Effects of Low Intensity Laser Irradiation During Healing of Skin Lesions in the Rat. Canadian Institutes of Health Research. Lasers Surg. Med., 41, 372-381.

Paramita, A. 2016. Pengaruh Pemberian Salep Ekstrak Daun Binahong (Anredera cordifolia (ten) steenis) Terhadap Kepadatan Kolagen Tikus Putih (Rattus norvegicus) Yang Mengalami Luka Bakar [Skripsi]. Fakultas Kedokteran Hewan. Universitas Airlangga. Surabaya. 13-28.

Pradhan, C., Monhanty, M., Rout, A. 2012. Phytochemical Screening And Comparative Bioefficacy Assessment Of Artocarpus Altilis Leaf Extracts For Antimicrobial Activity. Front. In Life Sci, 2(3), 72.

Pradipta, I.G. 2010. Pengaruh Pemberian Propolis Secara Topikal Terhadap Migrasi
Sel Polimorfonuklear Pada Luka Sayat Tikus. Fakultas Kedokteran. Universitas Jember.

Purnama, M.T.E., Samik, A. 2014. Potential mycotoxin binders on histopathology of the mammary gland experiencing neoplasia in pregnant mice (Mus musculus) with exposed zearalenone. Vet. Med, 7(1), 73-80.

Putri, S., Djamal, A., Rahmatini, R., Ilmiawati, C. 2015. Perbandingan Daya Hambat Larutan Antiseptik Povidone iodine dengan Ekstrak Daun Sirih terhadap Candida albicans secara In Vitro. J. Kes. Andalas, 4(3).

Rahmawati, R., Hanang, R. 2013. Povidone Iodine 10\% Dan Daun Sirih Dalam Mempercepat Penyembuhan Luka Bersih Marmut. Program Studi Ilmu Keperawatan. Universitas Gresik. J. Ners Commun., 4(1), 52-57.

Rohmawati, N. 2008. Efek Penyembuhan Luka Bakar Dalam Sediaan Gel Ekstrak Etanol 70\% Daun Lidah Buaya (Aloe Vera L.) Pada Kulit Punggung Kelinci New Zealand. [Skripsi]. Fakultas Farmasi Universitas Muhammadiyah Surakarta.

Singer, A.J., Dagum, A.B. 2008. Current Management Of Acute Cutaneus Wound. Engl. J. Med., 359(10), 1037-46.

Sucita, R.E., Hamid, I.S., Fikri, F., Purnama, M.T.E. 2019. Ekstrak Etanol Kayu Secang (Caesalpinia sappan L.) Secara Topikal Efektif pada Kepadatan Kolagen Masa Penyembuhan Luka Insisi Tikus Puth. J. Med. Vet., 2(2), 119-126. 